\title{
Isolation and Identification of Poly $\beta$-Hydroxybutyrate Over-Producing Bacteria and Optimization of Production Medium
}

\author{
Akram Hoseinabadi ${ }^{1}$; Iraj Rasooli ${ }^{1,{ }^{*}}$; Mojtaba Taran ${ }^{2}$ \\ ${ }^{1}$ Department of Biology, Shahed University, Tehran, IR Iran \\ ${ }^{2}$ Department of Biology, Razi University, Kermanshah, IR Iran \\ *Corresponding author: Iraj Rasooli, Department of Biology, Shahed University, Tehran, IR Iran. Tel:+98-2151212200, Fax: +98-2151212201, E-mail: rasooli@shahed.ac.ir
}

Received: December 17, 2013; Revised: March 6, 2014; Accepted: March 14, 2014

\begin{abstract}
Background: Biodegradable polyesters are candidates for the development of environmental friendly plastics. Poly- $\beta$-hydroxybutyrate (PHB) is a type of polyester from the hydroxyalkanoates family, synthesized by bacteria as an intracellular material and accumulated as granules in the cytoplasm.

Objectives: The aim of this study was to isolate Poly $\beta$-hydroxybutyrate over producing bacteria and optimize the production medium. Materials and Methods: A variety of PHB-accumulating bacterial strains were isolated from Kermanshah oil refinery sludge in Iran. Poly$\beta$-hydroxybutyrate-producing bacterial strains were confirmed by the gas chromatography method. The strain with the highest rate of $\mathrm{PHB}$ production was selected. Use of sugar cane molasses, a by-product of the sugar refinery industry, was investigated for the production of PHB. Plackett-Burman statistical method was employed to obtain factors in cell growth and PHB production. Optimization by the Response Surface Method (RSM) was done via two carbon sources, glucose and molasses.

Results: In the present study, 21 of 63 strains isolated from the refinery oil sludge produced PHB, seven of which were over producers. Poly$\beta$-hydroxybutyrate production was analyzed by Sudan Black B staining, spectrophotometric and gas chromatography (GC) methods. The strain with the highest rate of PHB production was used to optimize the culture medium. Fifteen factors were analyzed in PHB production by the Plackett-Burman method to find the most effective factors. Five important factors were optimized by RSM. Molasses were used as a cheap source of carbon. The maximum PHB obtained from molasses was $6.62 \mathrm{~g} / \mathrm{L}$. The phenotypic and $16 \mathrm{~S}$ rRNA biotyping tests led to the identification of the isolate as Bacillus coagulans.
\end{abstract}

Conclusions: The results suggest that $B$. coagulans is a good candidate for the fermentative production of PHB.

Keywords: $\beta$-hydroxybutyrate; Beta Hydroxybutyrate; Fermentation; Biodegradation; Plastics

\section{Background}

Plastics are widely used in packaging, building materials and commodities (1). Plastics are non-biodegradable petroleum derivatives considered as environmentally harmful wastes (2). In the recent years, biodegradable plastics have received attention for environmental compatibility and can be produced from renewable resources using various procedures (3). Among these biologically originated and biodegradable polymers, the family of polyhydroxyalkanoates (PHAs) is one of the best-studied cases. Polyhydroxyalkanoates are polyesters accumulated as intracellular granules by many microorganisms and act as supplies of carbon or energy (4). Poly- $\beta$-hydroxybutyrate (PHB) is the best studied and characterized PHA isolated and characterized for the first time by French microbiologist Maurice Lemoigne in 1923 (5). Poly- $\beta$-hydroxybutyrate is a biodegradable thermoplastic polyester applicable in almost all industries such as medicine, agriculture, etc.(6). This polymer can be used to encapsulate proteins, drugs and enzymes, providing sustained release and protec- tion of unreleased protein from degradation (7). The major problem preventing the commercial application of PHBs is their high price. One of the requirements for decreasing the production costs is the development of better PHB-producing bacterial strains (8).

During oil production and processing, significant quantities of oily sludge are generated. The oil sludge, frequently present in oil products stored in tanks, contains different concentrations of waste oil (40-60\%), waste water (30 - 90\%) and mineral particles (5 - 40\%) (5). Accumulation of PHB under aerobic conditions often occurs when the carbon source is in excess, but one or several other nutrients are limited. The oil sludge governs the conditions by providing excess carbon source and therefore, can be a good source for the accumulation of this polymer by bacteria. The price of PHB depends mainly on substrate cost, which accounts for about $40 \%$ of the total production costs (3). There are plenty of low-cost, renewable, carbon-containing raw materials available around the world. Sugarcane molasses are one such renewable

Copyright (C) 2015, Ahvaz Jundishapur University of Medical Sciences. This is an open-access article distributed under the terms of the Creative Commons Attribution-NonCommercial 4.0 International License (http://creativecommons.org/licenses/by-nc/4.0/) which permits copy and redistribute the material just in noncommercial usages, provided the original work is properly cited. 
Hoseinabadi A et al.

agricultural commodity. Molasses contain vitamins and other minor constituents that can be used as sources of carbon for PHB production (9).

One solution for the problem of high production cost is the optimization of cultivation media. Medium optimization for over production of any metabolite is an important step for its commercial use and involves a number of physicochemical parameters such as the composition of the medium, the carbon and nitrogen sources, minerals and trace metals, $\mathrm{pH}$, temperature, aeration and inoculum age. Optimization has been studied widely and typical optimization methods involve changing one factor or varying several factors at the same time (10). Statistical modeling of experiments has been used in many studies. Application of statistical methods involving the Plackett-Burman Design (PBD) has gained a lot of impetus for medium optimization and understanding the interactions among various physicochemical parameters (11). Response Surface Methodology (RSM) is a collection of mathematical and statistical techniques widely used to determine the ef fects of several variables and to optimize different biotechnological processes (5). Some studies have reported the use of RSM by different bacterial strains such as Rhodobacter sphaeroides and R. eutropha to increase PHB production (12).

\section{Objectives}

Biodegradable plastics can be produced from renewable resources. Many microorganisms accumulate PHAs in the form of intracellular granules as carbon supplies, exploitation of which could contribute significantly to maintenance of clean and green environment. This study deals with the isolation of poly- $\beta$-hydroxybutyrate producing bacterial strains and use of sugar cane molasses, a by-product of the sugar refinery industry for its production.

\section{Materials and Methods}

\subsection{Sample Collection}

Oily sludge samples were collected from the oil refinery of Kermanshah, Iran. The sampling was done through the terminal valve of the petroleum reservoirs after letting the sludge settle down. The sludge samples were collected directly from 20 tanks and poured in a 20-liter can and used throughout the study. The sample was stored at $4^{\circ} \mathrm{C}$ in the dark.

\subsection{Isolation of Bacteria}

Firstly, $20 \mathrm{mg}$ of the oily sludge was mixed with Tween 80 and transferred into Luria Bertani (LB) broth (Merck, Germany) and incubated at $30^{\circ} \mathrm{C}$ for 24 hours. After 24 hours, $0.1 \mathrm{~mL}$ of the growth medium was transferred to LB agar medium and bacterial isolation was carried out by repetitive culturing on LB agar plates.

\subsection{Observation of Poly- $\beta$-hydroxybutyrate Granules}

Sudan Black B (Merck, Germany), as a dye with particular high affinity for PHB granules, was used to screen the PHB-producing bacterial strains (presumptive test) (13).

\subsection{Quantitative Analysis of Poly- $\beta$-hydroxybutyrate}

The quantitative assessment process was performed by Ultra Violet (UV) spectrophotometry (PG Instrument, UK) for the strains (14). Positive bacterial colonies were selected for quantitative analysis. A loop of bacterial colonies was transferred to $50 \mathrm{~mL}$ of Mineral Salt Medium (MSM) (15) in $250 \mathrm{~mL}$ Erlenmeyer, and incubated on a rotary shaker incubator at $30^{\circ} \mathrm{C}$ and $150 \mathrm{rpm}$ for 48 hours (16). In order to determine the maximum PHB production time, the dry weight of PHB production was simultaneously checked. Quantitative measurement was done for $24-84$ hours by digesting the bacterial cells with $30 \%$ sodium hypochlorite solution at $37^{\circ} \mathrm{C}$ for 20 minutes, and separation of the residue by centrifugation at $8000 \times \mathrm{g}$ for 20 minutes. The residue was then successively washed with water, acetone and ethanol, dissolved in chloroform and was kept at $30^{\circ} \mathrm{C}$ for complete evaporation. Next, $5 \mathrm{~mL}$ of concentrated $\mathrm{H}_{2} \mathrm{SO}_{4}$ was added and heated for 40 minutes at $100^{\circ} \mathrm{C}$ in a water bath. The PHB was acidified with sulfuric acid for crotonic acid formation. Finally, the solution was analyzed by UV spectrophotometer at $235 \mathrm{~nm}$.

\subsection{Gas Chromatography (GC)}

Gas chromatography is generally used for rapid determination of PHB present in cells. For this purpose $20 \mathrm{mg}$ of PHB standard from Sigma-Aldrich was used, and the methyl esters of the 3-hydroxybutyrate were prepared as described by Lageveen et al. (16). Suspension of $20 \mathrm{mg}$ of lyophilized cells was made in $2 \mathrm{~mL}$ of methanol (Merck, Germany) containing 7\% (v/v) concentrated $\mathrm{H}_{2} \mathrm{SO}_{4}$ (Merck, Germany), in a tube with a Teflon-lined cap. Benzoic acid (Merck, Germany) was added as an internal standard. After addition of $4 \mathrm{~mL}$ of chloroform (Merck, Germany), the mixture was incubated for 2.5 hours in a water bath at $100^{\circ} \mathrm{C}$. The tubes were cooled down to room temperature. Furthermore, $4 \mathrm{~mL}$ of distilled water was added to the tubes, shaken for one minute and rapidly transferred on ice. The bottom organic layer containing PHB was later dried over sodium sulfate (Merck, Germany) before analysis. The organic phase, i.e. methyl esters, extracted by centrifugation at $4500 \times \mathrm{g}$ for five minutes, was analyzed by a gas chromatograph (Varian CP3800) equipped with a Flame Ionization Detector (FID) detector. The capillary column was a HP-5 from Agilent J \& W Scientific, $30 \mathrm{~m}$ in length with $0.25 \mathrm{~mm}$ internal diameter. The injection split ratio was 120:1. The injection port and the detector temperatures were $180^{\circ} \mathrm{C}$ and $200^{\circ} \mathrm{C}$, respectively. The initial oven temperature was maintained for one minute at $90^{\circ} \mathrm{C}$ with an increase of 
Hoseinabadi A et al.

$8^{\circ} \mathrm{C} /$ minute to a final temperature of $150^{\circ} \mathrm{C}$ (maintained for five minutes). The flow rate of the helium carrier gas was $1 \mathrm{~mL} /$ minute. The PHB polymer (Sigma) was used as an external standard.

\subsection{Determination of Cell Dry Weight}

The cell dry weight was measured by centrifugation with $100 \mathrm{~mL}$ of the culture at $5000 \times \mathrm{g}$ for 15 minutes at $4^{\circ} \mathrm{C}$. The cell pellet was washed in deionized water and dried at $80^{\circ} \mathrm{C}$ until a constant weight was achieved.

\subsection{Plackett-Burman Design}

Plackett-Burman Design (PBD) was employed for selection of significant variables in PHB production. Application of statistical methods involving Plackett-Burman Design (PBD) has gained a lot of impetus for medium optimization (11). Each independent variable was tested at two levels, a high (+1) level and a low (-1) level. The significant principal effects of each variable on $\mathrm{PHB}$ production were determined via the P-value.

\subsection{Optimization by Response Surface Methodol- ogy (RSM)}

Design Expert 7.1.6 software was used for medium optimization using the Box Behnken design. The software Design Expert was used for regression analysis of experimental data and also to plot the response surface graphs. Analysis of Variance (ANOVA) was used to estimate the statistical parameters. The studied response was $\mathrm{PHB}(\mathrm{g} / \mathrm{L})$.

\subsection{Characterization of the Isolated Bacteria}

Pure isolates containing PHB were investigated based on their microscopic, morphological and biochemical properties according to Bergey's Manual of Determinative Bacteriology (17).

\subsubsection{S rDNA 16S rRNA Gene Sequence Analysis}

The genomic DNA was extracted from isolated culture using the genomic DNA Extraction kit (Bioneer, Korea). The sequences were amplified using primers $27 \mathrm{~F}$ (5AGA GTT TGA TCM TGG CTC AG-3) and 1492 R (5-TAC GGY TAC CTT GTT ACG ACT T-3) (18). The Polymerase Chain Reaction (PCR) mixture contained $2 \mu \mathrm{L}$ of purified DNA template, $1.5 \mu \mathrm{L}$ of each primer, $2 \mu \mathrm{L}$ of deoxynucleoside triphosphates (dNTPs), $0.2 \mu \mathrm{L}$ of Taq DNA polymerase ( 5 $\mathrm{U} / \mu \mathrm{L}), 2 \mu \mathrm{L}$ of $\mathrm{MgCl}_{2}, 2 \mu \mathrm{L}$ PCR buffer and $9 \mu \mathrm{L}$ deionized water. The thermal cycling program used was as follows: initial denaturation at $94^{\circ} \mathrm{C}$ for five minutes, 35 cycles consisting of $94^{\circ} \mathrm{C}$ for one minute, $61^{\circ} \mathrm{C}$ for one minute, and $72^{\circ} \mathrm{C}$ for one minute, and a final extension step at $72^{\circ} \mathrm{C}$ for 1.5 minutes. The amplified PCR products were analyzed by electrophoresis (Bio Rad, USA). The sequences of the partial 16S rDNA were compared with the $16 \mathrm{~S}$ rDNA sequences available in the public nucleotide data- bases at the National Center for Biotechnology Information (NCBI).

\section{Results}

\subsection{Screening of Bacteria Accumulating Polyhy- droxyalkanoates}

Sixty-three bacterial strains were isolated from the oily sludge sample. Twenty-one of the colonies exhibited the ability to produce PHAs inclusion bodies.

\subsection{Quantitative Analysis of Poly- $\beta$-hydroxybutyrate}

Comparison of cell growth and PHB content ended up in selection of seven bacterial strains with high PHB content. An effective producer of PHB was chosen based on the dry weight of the extracted PHB. Poly- $\beta$ hydroxybutyrate yields of $0.98,1.78,2.18$ and $1.98 \mathrm{mg} / \mathrm{mL}$ were achieved after 48, 60, 72 and 84 hours. Maximum PHB synthesis occurred at 72 hours.

\subsection{Gas Chromatography (GC)}

Gas chromatography results (Figure 1) showed that the seven bacterial strains could accumulate PHB. Gas chromatography is used for rapid determination of the amount of PHA in cells and identification of the constituents of different hydroxyalkanoic acids. Results of GC showed that seven bacterial strains could accumulate PHB. Gas chromatography analysis confirmed that strain No. 43 produced high amounts of PHB.

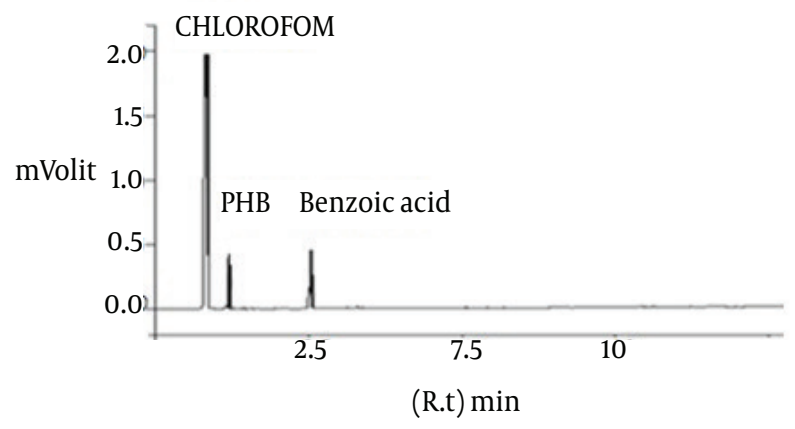

Figure 1. Chromatogram of Strain 43 Confirming High Production of Poly- $\beta$-hydroxybutyrate

\subsection{Plackett-Burman (PB) Experimental Design}

Plackett-Burman design was used to identify significant variables effective on $\mathrm{PHB}$ production. The PB experimental design for 20 trials with two levels of each variable is shown in Table 1 . The significant factors and levels $(\mathrm{g} / \mathrm{L})$ of variables for Box Behnken design, each of which were assessed at three coded levels of $-1,0$ and +1 , were 10,20 
and $30 \mathrm{~g} / \mathrm{L}$ for utilized carbon sources, 1,2 and $3 \mathrm{~g} / \mathrm{L}$ for $\left(\mathrm{NH}_{4}\right)_{2} \mathrm{SO}_{4}, 0.1,0.2$ and $0.3 \mathrm{~g} / \mathrm{L}$ for $\mathrm{FeSO}_{4}, 0.1,0.35$ and 0.6 $\mathrm{g} / \mathrm{L}$ for $\mathrm{CuSO}_{4}$, and 1,2 and $3 \mathrm{~g} / \mathrm{L}$ for $\mathrm{KH}_{2} \mathrm{PO}_{4}$.

The experimental results of PHB production by a complete five factors three levels factorial experiment design with six central points are shown in Table 2. The experiment was done with glucose and then with molasses. The adequacy of the model was calculated, and the effects of the variables on the response and significant levels were screened via Student's t-test for ANOVA (Table 3). Factors with P-values of less than $0.05(\mathrm{P}<$ 0.05 ) were considered to have significant effects and were therefore selected for further optimization studies. Based on the statistical analysis, the factors with the greatest positive impacts on the production of PHB were identified as $\mathrm{CuSO}_{4}, \mathrm{FeSO}_{4}$, Glucose, $\mathrm{KH}_{2} \mathrm{PO}_{4}$, and $\left(\mathrm{NH}_{4}\right)_{2} \mathrm{SO}_{4}$. A P-value of 0.001 indicated that glucose had the most significant positive effect on PHB production followed by $\left(\mathrm{NH}_{4}\right)_{2} \mathrm{SO}_{4}(\mathrm{P}=0.011), \mathrm{FeSO}_{4}(\mathrm{P}=0.014)$, $\mathrm{CuSO}_{4}(\mathrm{P}=0.023)$ and $\mathrm{KH}_{2} \mathrm{PO}_{4}(\mathrm{P}=0.031)$. Factors such as $\mathrm{MgSO}_{4}$, temperature, inoculum, inoculum age, $\mathrm{CaCl}_{2}$, $\mathrm{Na}_{2} \mathrm{HPO}_{4}, \mathrm{ZnSO}_{4}$, aeration, $\mathrm{pH}$ and the liquid volume did not have significant effects on PHB production. In the Pareto chart, the most important factors are presented in the upper portion while lower rows indicate the least important factors. The optimum levels of the five variables, i.e. Glucose, $\left(\mathrm{NH}_{4}\right)_{2} \mathrm{SO}_{4}$, $\mathrm{FeSO}_{4}, \mathrm{CuSO}_{4}$ and $\mathrm{KH}_{2} \mathrm{PO}_{4}$, were further determined by the RSM design.

Table 1. Twenty-Trial Plackett-Burman Design Matrix for Fifteen Variables Predicted for Poly- $\beta$-hydroxybutyrate Production

Experimental Values

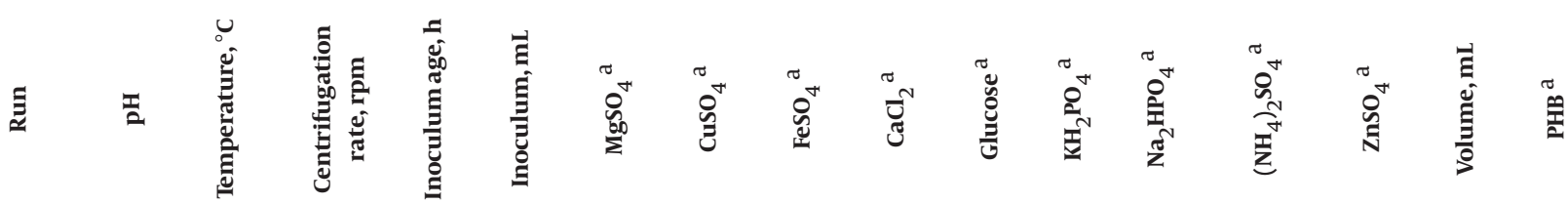

\begin{tabular}{|c|c|c|c|c|c|c|c|c|c|c|c|c|c|c|c|c|}
\hline 1 & 9 & 25 & 200 & 12 & 10 & 0.0 & 0.0 & 0.0 & 0.1 & 10 & 1 & 0 & 2 & 0.1 & 100 & 0.090 \\
\hline 2 & 9 & 35 & 100 & 24 & 10 & 0.0 & 0.0 & 0.0 & 0.0 & 30 & 0 & 2 & 0 & 0.1 & 100 & 0.870 \\
\hline 3 & 7 & 35 & 200 & 24 & 5 & 0.5 & 0.0 & 0.0 & 0.0 & 10 & 1 & 0 & 2 & 0.0 & 100 & 0.940 \\
\hline 4 & 7 & 25 & 200 & 12 & 10 & 0.5 & 0.1 & 0.0 & 0.0 & 10 & 0 & 2 & 0 & 0.1 & 50 & 0.070 \\
\hline 5 & 9 & 25 & 100 & 24 & 10 & 0.0 & 0.1 & 0.2 & 0.0 & 10 & 0 & 0 & 2 & 0.0 & 100 & 1.350 \\
\hline 6 & 9 & 35 & 100 & 24 & 5 & 0.5 & 0.0 & 0.2 & 0.1 & 10 & 0 & 0 & 0 & 0.1 & 50 & 0.050 \\
\hline 7 & 9 & 35 & 200 & 12 & 5 & 0.5 & 0.1 & 0.0 & 0.1 & 30 & 0 & 0 & 0 & 0.0 & 100 & 1.890 \\
\hline 8 & 9 & 35 & 200 & 12 & 10 & 0.0 & 0.1 & 0.2 & 0.0 & 30 & 1 & 0 & 0 & 0.0 & 50 & 3.090 \\
\hline 9 & 7 & 35 & 200 & 24 & 10 & 0.0 & 0.0 & 0.2 & 0.1 & 10 & 1 & 2 & 0 & 0.0 & 50 & 1.660 \\
\hline 10 & 9 & 25 & 200 & 24 & 10 & 0.5 & 0.0 & 0.0 & 0.1 & 30 & 0 & 2 & 2 & 0.0 & 50 & 1.950 \\
\hline 11 & 7 & 35 & 100 & 24 & 10 & 0.5 & 0.1 & 0.0 & 0.0 & 30 & 1 & 0 & 2 & 0.1 & 50 & 4.350 \\
\hline 12 & 9 & 25 & 200 & 24 & 5 & 0.5 & 0.1 & 0.2 & 0.0 & 10 & 1 & 2 & 0 & 0.1 & 100 & 1.280 \\
\hline 13 & 7 & 35 & 100 & 12 & 10 & 0.5 & 0.1 & 0.2 & 0.1 & 10 & 0 & 2 & 2 & 0.0 & 100 & 1.650 \\
\hline 14 & 7 & 25 & 200 & 24 & 5 & 0.0 & 0.1 & 0.2 & 0.1 & 30 & 0 & 0 & 2 & 0.1 & 50 & 3.670 \\
\hline 15 & 7 & 25 & 100 & 12 & 10 & 0.5 & 0.0 & 0.2 & 0.1 & 30 & 1 & 0 & 0 & 0.1 & 100 & 1.990 \\
\hline 16 & 7 & 25 & 100 & 24 & 5 & 0.0 & 0.1 & 0.0 & 0.1 & 30 & 1 & 2 & 0 & 0.0 & 100 & 2.340 \\
\hline 17 & 9 & 25 & 100 & 12 & 5 & 0.5 & 0.0 & 0.2 & 0.0 & 30 & 1 & 2 & 2 & 0.0 & 50 & 3.350 \\
\hline 18 & 9 & 35 & 100 & 12 & 5 & 0.0 & 0.1 & 0.0 & 0.1 & 10 & 1 & 2 & 2 & 0.1 & 50 & 1.870 \\
\hline 19 & 7 & 35 & 200 & 12 & 5 & 0.0 & 0.0 & 0.2 & 0.0 & 30 & 0 & 2 & 2 & 0.1 & 100 & 2.570 \\
\hline 20 & 7 & 25 & 100 & 12 & 5 & 0.0 & 0.0 & 0.0 & 0.0 & 10 & 0 & 0 & 0 & 0.0 & 50 & 0.009 \\
\hline
\end{tabular}

a Data are presented as $\mathrm{g} / \mathrm{L}$. 
Hoseinabadi A et al.

Table 2. Box Behnken Design Matrix for the Experimental Design of Poly- $\beta$-hydroxybutyrate (PHB) Production Media With Corresponding Results

\begin{tabular}{|c|c|c|c|c|c|c|c|c|c|}
\hline \multirow[t]{2}{*}{ Trails } & \multicolumn{5}{|c|}{ Coded Factors } & \multicolumn{4}{|c|}{ Responses PHB, g/L } \\
\hline & $\mathbf{A}$ & B & C & D & $\mathbf{E}$ & Observed Glucose & Predicted Glucose & Observed Molasses & Predicted Molasses \\
\hline $\mathbf{1}$ & 0 & 0 & -1 & -1 & 0 & 1.41 & 1.97 & 2.9 & 3.81 \\
\hline 2 & 0 & 1 & 1 & 0 & 0 & 1.09 & 1.60 & 3.5 & 3.18 \\
\hline 3 & -1 & 0 & 1 & 0 & 0 & 0.55 & 0.83 & 0.89 & 1 \\
\hline 4 & 0 & 0 & 0 & 0 & 0 & 4.02 & 4.22 & 6.62 & 6.36 \\
\hline 5 & 0 & -1 & 0 & 0 & 1 & 1.12 & 1.88 & 3.9 & 3.94 \\
\hline 6 & 1 & 0 & 1 & 0 & 0 & 0.29 & 0.83 & 0.58 & 1.96 \\
\hline 7 & 0 & 0 & 0 & 0 & 0 & 3.85 & 4.22 & 5.98 & 6.36 \\
\hline 8 & 0 & -1 & 0 & 1 & 0 & 1.98 & 1.33 & 4.02 & 3.13 \\
\hline 9 & -1 & 0 & 0 & -1 & 0 & 0.09 & 0.30 & 0.17 & 0.11 \\
\hline 10 & 1 & 0 & 0 & 0 & 1 & 0.61 & 0.19 & 0.97 & 0.78 \\
\hline 11 & 0 & 0 & 0 & 1 & 1 & 0.1 & 0.65 & 0.29 & 1.53 \\
\hline 12 & -1 & 0 & 0 & 1 & 0 & 0.11 & 0.38 & 0.28 & 0.99 \\
\hline 13 & 0 & 0 & 0 & 1 & -1 & 1.01 & 1.35 & 3.2 & 2.79 \\
\hline 14 & 0 & 0 & 1 & 1 & 0 & 1.02 & 1.29 & 3.04 & 2.71 \\
\hline 15 & 1 & 0 & 0 & 1 & 0 & 0.27 & 0.38 & 0.56 & 0.03 \\
\hline 16 & -1 & -1 & 0 & 0 & 0 & 0.09 & 0.87 & 0.02 & 1.42 \\
\hline 17 & 0 & 0 & -1 & 1 & 0 & 0.32 & 1.29 & 0.63 & 2.71 \\
\hline 18 & 0 & 1 & -1 & 0 & 0 & 2.28 & 1.60 & 4.8 & 3.18 \\
\hline 19 & 0 & -1 & 0 & 0 & -1 & 2.48 & 2.60 & 4.9 & 5.2 \\
\hline 20 & 0 & -1 & 0 & -1 & 0 & 2.93 & 2.1 & 5.01 & 4.23 \\
\hline 21 & 1 & 0 & -1 & 0 & 0 & 0.71 & 0.83 & 1.08 & 3.62 \\
\hline 22 & 1 & 0 & 0 & 0 & -1 & 0.95 & 0.89 & 1.71 & 2.04 \\
\hline 23 & -1 & 0 & 0 & 0 & -1 & 0.36 & 0.89 & 0.77 & 1.08 \\
\hline 24 & 0 & 0 & 0 & -1 & 1 & 0.92 & 1.33 & 1.82 & 2.63 \\
\hline 25 & 0 & -1 & 1 & 0 & 0 & 2.08 & 2.54 & 4.3 & 5.12 \\
\hline 26 & 0 & 0 & 0 & -1 & -1 & 1.98 & 2.03 & 4.1 & 3.89 \\
\hline 27 & 0 & 0 & -1 & 0 & -1 & 3.74 & 2.56 & 5.85 & 4.78 \\
\hline 28 & 1 & 1 & 0 & 0 & 0 & 0.65 & 0.07 & 0.92 & 0.44 \\
\hline 29 & 0 & 0 & -1 & 0 & 1 & 3.12 & 1.89 & 5.12 & 3.52 \\
\hline 30 & 0 & -1 & -1 & 0 & 0 & 3.04 & 2.54 & 5.04 & 5.12 \\
\hline 31 & 0 & 1 & 0 & -1 & 0 & 0.78 & 1.07 & 1.61 & 2.29 \\
\hline 32 & 0 & 0 & 0 & 0 & 0 & 4.41 & 4.22 & 6.56 & 6.36 \\
\hline 33 & 0 & 1 & 0 & 1 & 0 & 0.68 & 0.39 & 1.02 & 1.19 \\
\hline 34 & 0 & 1 & 0 & 0 & 1 & 0.62 & 0.96 & 0.91 & 2.08 \\
\hline 35 & 0 & 1 & 0 & 0 & -1 & 1 & 1.31 & 2.28 & 3.26 \\
\hline 36 & -1 & 0 & -1 & 0 & 0 & 0.18 & 0.83 & 0.39 & 1 \\
\hline 37 & 1 & -1 & 0 & 0 & 0 & 1.03 & 0.87 & 3.3 & 2.38 \\
\hline 38 & 0 & 0 & 1 & 0 & 1 & 2.11 & 1.86 & 4.41 & 3.52 \\
\hline 39 & -1 & 1 & 0 & 0 & 0 & 0.003 & 0.07 & 0.01 & 0.52 \\
\hline 40 & 0 & 0 & 0 & 0 & 0 & 4.39 & 4.22 & 6.64 & 6.36 \\
\hline 41 & 0 & 0 & 0 & 0 & 0 & 4.35 & 4.22 & 6.16 & 6.36 \\
\hline 42 & -1 & 0 & 0 & 0 & 1 & 0.22 & 0.19 & 0.38 & 0.18 \\
\hline 43 & 0 & 0 & 0 & 0 & 0 & 4.28 & 4.22 & 6.22 & 6.36 \\
\hline 44 & 0 & 0 & 1 & 0 & -1 & 3.01 & 2.56 & 5.01 & 4.78 \\
\hline 45 & 0 & 0 & 1 & -1 & 0 & 2.02 & 1.97 & 4.7 & 3.81 \\
\hline 46 & 1 & 0 & 0 & -1 & 0 & 0.85 & 0.30 & 1.53 & 1.07 \\
\hline
\end{tabular}


Hoseinabadi A et al.

Table 3. Estimated Effect, Regression Coefficient and Corresponding " $t$ " and "P" Values for Poly- $\beta$-hydroxybutyrate Production in Fifteen Variable Plackett-Burman Design Experiments

\begin{tabular}{|c|c|c|c|c|c|}
\hline Term & Effect & Coef & SE Coef & $\mathbf{T}$ & $\mathbf{P}$ \\
\hline Constant & & 17519 & 0.09627 & 18.20 & 0.000 \\
\hline pH & -0.3459 & -0.17729 & 0.09627 & -1.80 & 0.147 \\
\hline Temperature & 0.2841 & 0.1421 & 0.09627 & 1.48 & 0.214 \\
\hline Aeration & -0.0619 & -0.0310 & 0.09627 & -0.32 & 0.764 \\
\hline Inoculum & -0.0899 & -0.0450 & 0.09627 & -0.47 & 0.665 \\
\hline Inoculum age & 0.1881 & 0.0940 & 0.09627 & 0.98 & 0.384 \\
\hline $\mathrm{MgSO}_{4}$ & 0.0001 & 0.0001 & 0.09627 & 0.00 & 1.000 \\
\hline $\mathrm{FeSO}_{4}$ & 0.8081 & 0.4041 & 0.09627 & 4.20 & 0.014 \\
\hline $\mathrm{KH}_{2} \mathrm{PO}_{4}$ & 0.6281 & 0.3141 & 0.09627 & 3.26 & 0.031 \\
\hline $\mathrm{CaSO}_{4}$ & -0.0719 & -0.0359 & 0.09627 & -0.37 & 0.728 \\
\hline Carbon source & 1.7101 & 0.8550 & 0.09627 & 8.88 & 0.001 \\
\hline $\mathrm{CuSO}_{4}$ & 0.6881 & 0.3440 & 0.09627 & 3.57 & 0.023 \\
\hline $\mathrm{Na}_{2} \mathrm{HPO}_{4}$ & 0.0181 & 0.0090 & 0.09627 & 0.09 & 0.930 \\
\hline$\left(\mathrm{NH}_{4}\right)_{2} \mathrm{SO}_{4}$ & 0.8541 & 0.4271 & 0.09627 & 4.44 & 0.011 \\
\hline $\mathrm{ZnSO}_{4}$ & -0.1419 & 0.0710 & 0.09627 & -0.74 & 0.502 \\
\hline Volume & -0.5099 & -02550 & 0.09627 & -2.65 & 0.057 \\
\hline
\end{tabular}

\subsection{Response Surface Methodology}

Chosen factors were set based on the PB analysis. Fivefactor was studied at three-levels and 46 trials were done at $\mathrm{pH} 7$ and temperature of $37^{\circ} \mathrm{C}$. The statistical significance of the model equation was evaluated by the F-test for Analysis of Variance (ANOVA), which showed that $\left(\mathrm{NH}_{4}\right)_{2} \mathrm{SO}_{4}, \mathrm{CuSO}_{4}$ and $\mathrm{KH}_{2} \mathrm{PO}_{4}$ were significant $(\mathrm{P}<0.05)$ for glucose (Table 4). P-values of less than 0.05 indicated factors, which are significant at the probability level of 95\%. The F-value of 27.26 implies that the model is significant $(\mathrm{P}<0.0001)$. Lack of fit $(\mathrm{P}=0.0167)$ also suggested that the obtained experimental data had a good fit with the model. The second order polynomial equation was obtained based on the regression analysis. For glucose the Equation is:is:

$$
\begin{aligned}
\operatorname{PHB}\left(\frac{g}{L}\right)= & +4.22-0.47 \times B-0.34 \times D \\
& -0.35 \times E-2.53 \times A^{2}-1.29 \\
& \times B^{2}-0.86 \times C^{2}-1.73 \times D^{2}-1.15 \times E^{2}
\end{aligned}
$$

Analysis of Variance for the response surface quadratic model, presented in Table 4 for molasses, showed that effects of $\left(\mathrm{NH}_{4}\right)_{2} \mathrm{SO}_{4}(\mathrm{P}=0.0002)$ were more significant than the those of the other variables. $\mathrm{KH}_{2} \mathrm{PO}_{4}(\mathrm{P}=$ 0.0095), $\mathrm{CuSO}_{4}(\mathrm{P}=0.0213)$ and molasses $(\mathrm{P}=0.0412)$ had significant effects on PHB production. The F-value of 25.13 is significant $(\mathrm{P}<0.0001)$. The second order polynomial Equation for for molasses is:

$$
\begin{aligned}
\operatorname{PHB}\left(\frac{g}{L}\right)= & +6.36+0.48 \times A-0.97 \times B-0.55 \\
& \times D-0.63 \times E-4.05 \times A^{2}-1.38 \\
& \times B^{2}-0.83 \times C^{2}-2.27 \times D^{2}-1.38 \times E
\end{aligned}
$$

Where $\mathrm{A}$ is the carbon source $(\mathrm{g} / \mathrm{L})$; $\mathrm{B}$ is $\left(\mathrm{NH}_{4}\right)_{2} \mathrm{SO}_{4}(\mathrm{~g} / \mathrm{L})$; C is $\mathrm{FeSO}_{4}(\mathrm{~g} / \mathrm{L})$, D is $\mathrm{CuSO}_{4}(\mathrm{~g} / \mathrm{L})$ and $\mathrm{E}$ is $\mathrm{KH}_{2} \mathrm{PO}_{4}(\mathrm{~g} / \mathrm{L})$.

According to the regression equation obtained from the ANOVA the $\mathrm{R}^{2}$ for glucose was 0.8549 , indicating that the model could explain $85.49 \%$ of the variability in the production of PHB. The $\mathrm{R}^{2}$ value was always between zero and one. The closer the $\mathrm{R}^{2}$ to one, the stronger is the model and the better it predicted the response. The amount for the carbon source, molasses was 0.8627. The "adjusted $\mathrm{R}^{2}$ " was 0.8284 and the "predicted $\mathrm{R}^{2}$ " was 0.7770 , which indicated that the model as good. The "adequate precision value" of the present model was 17.271, the "adequate precision value" is an index of the signal-to-noise ratio, and values of higher than four are essential prerequisites for a model to be a good fit (Table 4). 
Hoseinabadi A et al.

\begin{tabular}{|c|c|c|c|c|c|c|c|}
\hline Source & Carbon Source & Sum of Squares & df & Mean Square & F Value & P-Value, Prob $>$ F & Note \\
\hline \multirow[t]{2}{*}{ Model } & G & 75.39 & 8 & 9.429 & 27.26 & $<0.0001$ & $S$ \\
\hline & M & 188.80 & 9 & 20.98 & 25.13 & $<0.0001$ & $S$ \\
\hline \multirow{2}{*}{$\mathrm{B}-\left(\mathrm{NH}_{4}\right)_{2} \mathrm{SO}_{4}$} & G & 3.58 & 1 & 3.58 & 10.35 & 0.0027 & \\
\hline & M & 14.90 & 1 & 14.90 & 17.85 & 0.0002 & \\
\hline \multirow{2}{*}{$\mathrm{D}-\mathrm{CuSO}_{4}$} & G & 1.88 & 1 & 1.88 & 5.45 & 0.0251 & \\
\hline & M & 4.84 & 1 & 4.84 & 5.80 & 0.0213 & \\
\hline \multirow[t]{2}{*}{$\mathrm{E}-\mathrm{KH}_{2} \mathrm{PO}_{4}$} & G & 2.02 & 1 & 2.02 & 5.83 & 0.0208 & \\
\hline & M & 6.28 & 1 & 6.28 & 7.52 & 0.0095 & \\
\hline \multirow[t]{2}{*}{$A^{2}$} & G & 55.74 & 1 & 55.74 & 161.23 & $<0.0001$ & \\
\hline & M & 143.15 & 1 & 16.74 & 20.06 & $<0.0001$ & \\
\hline \multirow[t]{2}{*}{$\mathbf{B}^{2}$} & G & 14.50 & 1 & 14.50 & 41.93 & $<0.0001$ & \\
\hline & M & 16.74 & 1 & 16.74 & 20.06 & $<0.0001$ & \\
\hline \multirow[t]{2}{*}{$c^{2}$} & G & 6.39 & 1 & 6.39 & 18.48 & 0.0001 & \\
\hline & M & 5.96 & 1 & 5.96 & 7.15 & 0.0112 & \\
\hline \multirow[t]{2}{*}{$D^{2}$} & G & 26.14 & 1 & 26.14 & 75.61 & $<0.0001$ & \\
\hline & M & 45.10 & 1 & 45.10 & 54.04 & $<0.0001$ & \\
\hline \multirow[t]{2}{*}{$\mathbf{E}^{2}$} & G & 11.64 & 1 & 11.64 & 33.67 & $<0.0001$ & \\
\hline & M & 16.58 & 1 & 16.58 & 19.86 & $<0.0001$ & \\
\hline \multirow[t]{2}{*}{ Residual } & G & 12.79 & 37 & 0.35 & & & \\
\hline & M & 30.05 & 36 & 0.83 & & & \\
\hline \multirow[t]{2}{*}{ Lack of fit } & G & 12.53 & 32 & 0.39 & 7.46 & 0.0167 & $S$ \\
\hline & M & 29.66 & 31 & 0.96 & 12.27 & 0.0054 & $S$ \\
\hline \multirow[t]{2}{*}{ Pure error } & G & 0.26 & 5 & 0.052 & & & \\
\hline & M & 0.39 & 5 & 0.078 & & & \\
\hline \multirow[t]{2}{*}{ Cor total } & G & 88.18 & 45 & & & & \\
\hline & M & 218.85 & 45 & & & & \\
\hline \multirow[t]{2}{*}{ R-squared } & G & 0.8549 & AdjR-Squared & 0.8236 & & & \\
\hline & M & 0.8627 & & 0.8284 & & & \\
\hline \multirow{2}{*}{$\begin{array}{l}\text { Pred R- } \\
\text { squared }\end{array}$} & G & 0.7731 & Adeq precision & 17.691 & & & \\
\hline & M & 0.7770 & & 17.271 & & & \\
\hline
\end{tabular}

\footnotetext{
a Abbreviations: G, Glucose; M, Molasses; S, significant.
}

The effect of interaction of various nutrients on PHB production by molasses and glucose as the carbon sources was studied by plotting three-dimensional response surface curves. With the optimized medium, the production of PHB was found to be $6.36 \mathrm{~g} / \mathrm{L}$ of molasses and 4.21 $\mathrm{g} / \mathrm{L}$ of glucose. To sum up, the solution for an optimization-based regression equation via glucose as the carbon source was as follows: glucose: $19.03 \mathrm{~g} / \mathrm{L},\left(\mathrm{NH}_{4}\right)_{2} \mathrm{SO}_{4}: 1.35$ $\mathrm{g} / \mathrm{L}, \mathrm{FeSO}_{4}: 0.19 \mathrm{~g} / \mathrm{L}, \mathrm{CuSO}_{4}: 0.50 \mathrm{~g} / \mathrm{L}$ and $\mathrm{KH}_{2} \mathrm{PO}_{4}: 1.23 \mathrm{~g} / \mathrm{L}$. The optimum levels of each variable with molasses as the carbon source were as follows: Molasses: $19.20 \mathrm{~g} / \mathrm{L}$,
$\left(\mathrm{NH}_{4}\right)_{2} \mathrm{SO}_{4}: 1.85 \mathrm{~g} / \mathrm{L}, \mathrm{FeSO}_{4}: 0.14 \mathrm{~g} / \mathrm{L}, \mathrm{CuSO}_{4}: 0.13 \mathrm{~g} / \mathrm{L}$, and $\mathrm{KH}_{2} \mathrm{PO}_{4}: 2.43 \mathrm{~g} / \mathrm{L}$.

Figure 2 A shows a direct relationship between PHB production and concentrations of $\mathrm{CuSO}_{4}$ and glucose. Maximum PHB production was achieved when these two factors were at an intermediate level. Maximum response for $\mathrm{PHB}$ production occurred at $\mathrm{KH}_{2} \mathrm{PO}_{4}$ and glucose concentrations of about 0.35 and $20 \mathrm{~g} / \mathrm{L}$, respectively (Figure $2 \mathrm{~B}$ ). $\left(\mathrm{NH}_{4}\right)_{2} \mathrm{SO}_{4}$ and molasses affected $\mathrm{PHB}$ production at concentrations of slightly less than midlevel (Figure $2 \mathrm{C}$ ). 
Figure 2. Three-Dimensional Response Surface Curves Showing the Effect of Interaction of Various Components on the Production of Poly- $\beta$ hydroxybutyrate by the Isolated Strain

A

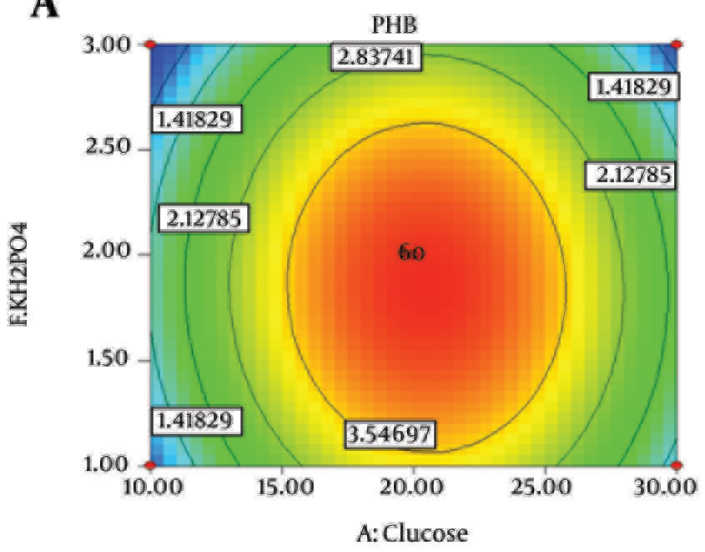

\section{B}
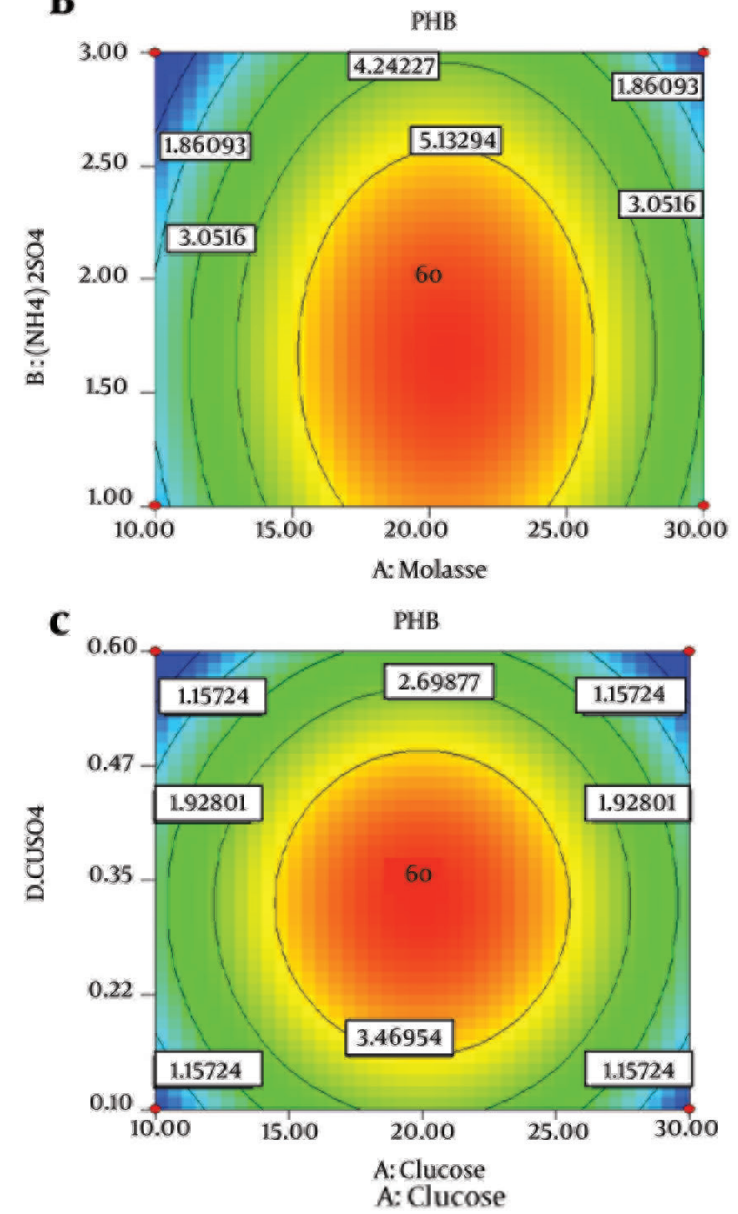
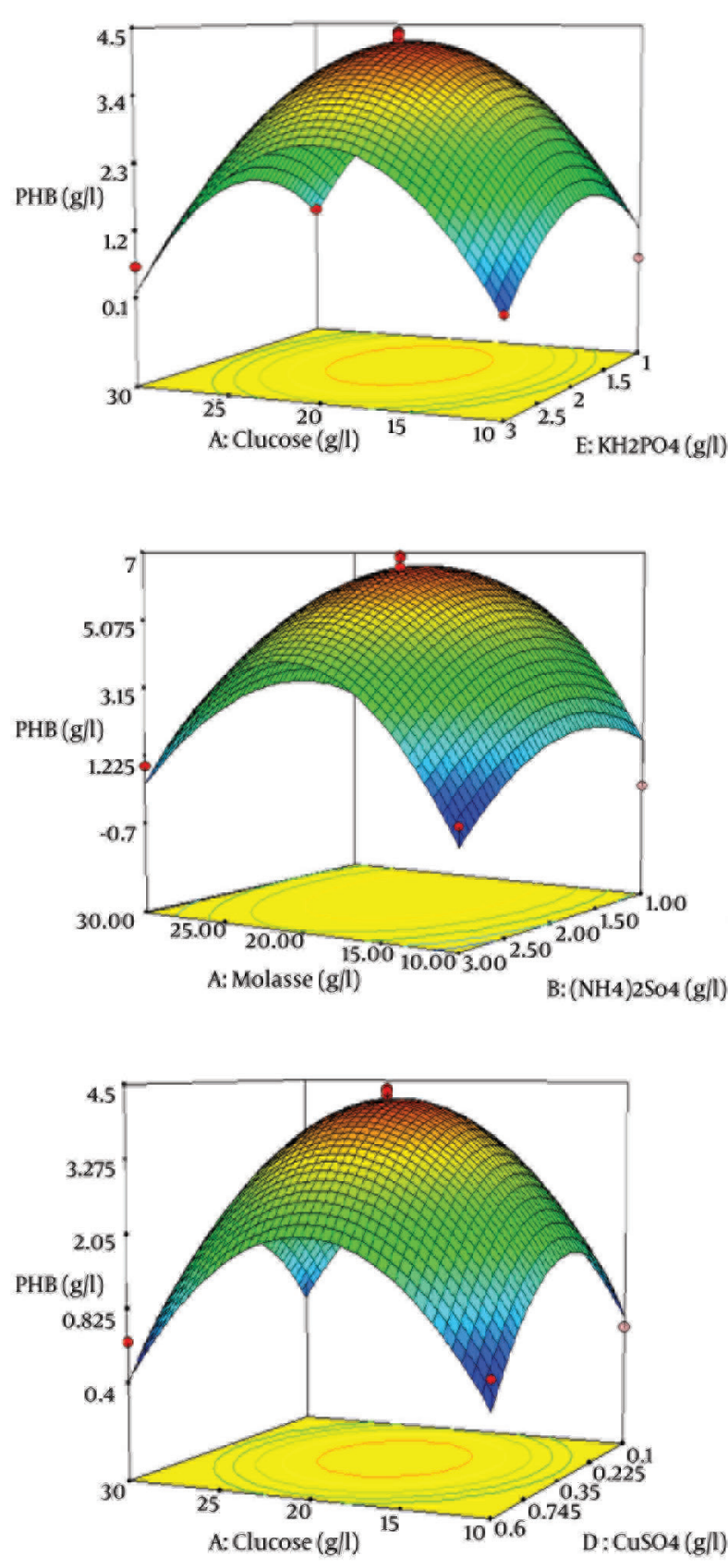

A): Glucose and $\left.\mathrm{CuSO}_{4}, \mathrm{~B}\right)$ : Glucose and $\left.\mathrm{KH}_{2} \mathrm{PO}_{4}, \mathrm{C}\right)$ : Molasses and $\left(\mathrm{NH}_{4}\right)_{2} \mathrm{SO}_{4}$.

\subsection{Characterization of the Isolated Bacteria}

Motility test, catalase, amylase, nitrate reduction, Methyl Red (MR), growth in $2 \% \mathrm{NaCl}$, growth at 10, 37 and 45 $-55^{\circ} \mathrm{C}$, sugar (glucose, lactose, sucrose, fructose and maltose) fermentation tests, were found to be positive. Indole, 
Hoseinabadi A et al.

VP (Voges-Proskauer) and $\mathrm{SH}_{2}$ tests, lipase, oxidase, gelatinase and urease production, growth in $5-10 \% \mathrm{NaCl}$, and growth at $5^{\circ} \mathrm{C}$ were negative for the isolate.

\subsection{Identification and Characterization of the Strain}

The strain isolated from the oil sludge was a gram-positive rod-shaped bacteria. The biochemical characterization of the isolate revealed that the strain belonged to the genus Bacillus. 16S rRNA 16SrDNA sequence (Figure 3) and BLAST at NCBI database revealed 99.96\% likelihood of the strain to Bacillus coagulans.

Figure 3. Polymerase Chain Reaction With Universal Primers

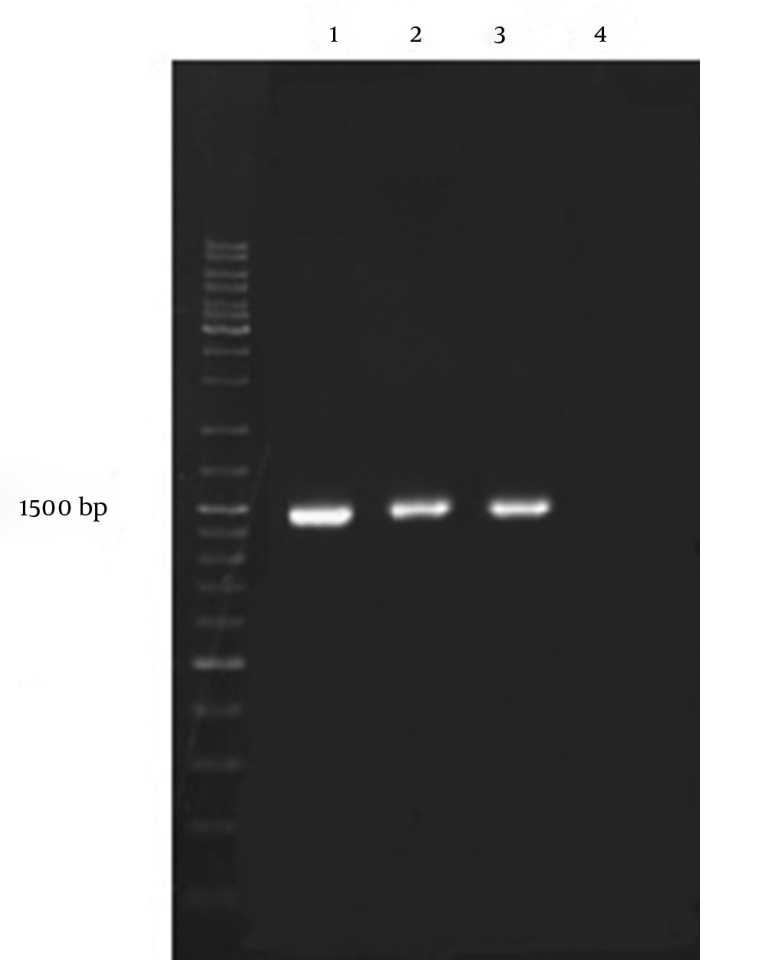

Lane 1: sample No. 43; Lanes 2 and 3: positive control; Lane 4: negative control.

\section{Discussion}

Environmental pollution as a result of petrochemical plastics has created renewed interest in biologically derived polymers, and PHB has been suggested to be a suitable candidate for the solution to the problem of petroleum, based non-degradable polymers. Poly- $\beta$ hydroxybutyrate can be degraded by various microorganisms (4). Furthermore, PHBs are now employed as drug carriers to release drug slowly during degradation, providing sustained effect of the drug, thereby reducing the doses of the drug required (19). Amongst different environments including soils with different properties, sea-water and deep-sea mud have been ports of PHB-producing bacteria isolation (20). Isolation of PHB-producing bacteria from oil sludge has not yet been reported. In this study, during the initial step, 63 bacterial strains were isolated from oil sludge. Pseudomonas citronellolis, Xanthobacter, Beijerinckia, Pseudomonas, Bacillus sp. and Acinetobacter sp. are among the bacteria isolated from activated sludge oil (21)

Suitable flocs of PHB yield can be obtained via optimizing the ex-situ operating strategy (22). Sustaining a controlled residual growth improves the PHB specific production rate without altering production yield (23). In the present study, the significant variables necessary for enhanced PHB production were selected using the Plackett-Burman design. Of the 15 variables under study, five effective variables were selected by the Plackett-Burman design experiment, including glucose, $\left(\mathrm{NH}_{4}\right)_{2} \mathrm{SO}_{4}$, $\mathrm{FeSO}_{4}, \mathrm{CuSO}_{4}$ and $\mathrm{KH}_{2} \mathrm{PO}_{4}$ concentrations. Mokhtari and co-workers (5) reported $\left(\mathrm{NH}_{4}\right)_{2} \mathrm{SO}_{4}$ and $\mathrm{KH}_{2} \mathrm{PO}_{4}$ as influential factors in increasing production efficiency. Our results of PHB production by B. coagulans are in agreement with their report. Trace elements such as iron and copper play an important role in the production of $\mathrm{PHB}$ in $\mathrm{B}$. coagulans. The validity of the RSM model is proved by fitting the values of the variables into a model equation (24).

Box-Behnken design was used to obtain optimum production of PHB by the isolated strain and the contour plots in 3D response depicted the variation in PHB yield, as a function of interaction of variables. Initially, glucose was used as the carbon source. The PHB producer, B. megaterium R11, was isolated in Singapore and could accumulate PHB up to 51.3\% of its cell dry weight (CDW) from both glucose and xylose. Tryptone was identified as its best nitrogen source. Poly- $\beta$-hydroxybutyrate content and production reached $58.5 \%$ and $9.32 \mathrm{~g} / \mathrm{L}$, respectively, for an overall Oil Palm Empty Fruit Bunch (OPEFB) sugar concentration of $45 \mathrm{~g} / \mathrm{L}$. These respectively reached $51.6 \%$ and $12.48 \mathrm{~g} / \mathrm{L}$ for OPEFB hydrolysate containing $60 \mathrm{~g} / \mathrm{L}$ sugar with a productivity of $0.260 \mathrm{~g} / \mathrm{L} /$ hour (25). In order to find a cheap carbon source, molasses was also used and the results were compared. Analysis of variance showed that the molasses was more effective than glucose in PHB production by this strain. Molasses had a greater influence on PHB concentration than glucose $(\mathrm{P}=0.0412)$.

Gouda and co-workers (10) reported that glucose and molasses as carbon sources, had great effects on PHB production. Since PHB is produced under high carbon source concentrations, molasses as a good glucose and sucrose source can enhance PHB production. Lee et al. (26) tested various carbon sources from wastes such as whey, cane and sugar beet molasses for production of PHB. They also used a mixture of different salts as mineral source. $\left(\mathrm{NH}_{4}\right)_{2} \mathrm{SO}_{4}$ is a good nitrogen source and a growth factor in $\mathrm{PHB}$ production $(\mathrm{P}=0.002) .\left(\mathrm{NH}_{4}\right)_{2} \mathrm{SO}_{4}$ has been used as the principal nitrogen source for optimal microbial growth and PHB production by Alcaligenes eutrophus and Halomonas boliviensis (27). It has been observed that 
the composition of trace elements in solutions also play important roles in the metabolic regulation of PHB accumulation in bacterial cells (28). Maximum PHB concentration could be achieved using molasses as carbon and $\left(\mathrm{NH}_{4}\right)_{2} \mathrm{SO}_{4}$ as nitrogen sources, and $\mathrm{KH}_{2} \mathrm{PO}_{4}$ and $\mathrm{CuSO}_{4}$ at medium concentrations. Poly- $\beta$-hydroxybutyrate obtained using molasses in this study was $6.36 \mathrm{~g} / \mathrm{L}$. This is comparable to maximum PHB production of $5.41 \mathrm{~g} / \mathrm{L}$ of $B$. megaterium (12) using molasses in batch culture.

A statistical design combining PB with RSM offers an efficient and feasible approach for PHB medium optimization. Furthermore, the optimum culture medium obtained in this experiment provided the basis for further studies in culture conditions with batch or fed-batch cultivation in a bioreactor for large-scale production. Finally, our results suggest that $B$. coagulans is a good candidate for the fermentative production of this biopolymer.

\section{Acknowledgements}

This study was supported by a grant from Shahed University of Tehran, Iran. The authors gratefully acknowledge the Department of Biology of Razi University, Kermanshah, Iran for the use of their chromatography equipment.

\section{Authors' Contributions}

Prof. Iraj Rasooli and Dr. Mojtaba Taran developed the original idea and analyzed the data. Akram Hoseinabadi contributed to the handling of the protocol, conducting the laboratory experimental work and prepared the manuscript. The manuscript was critically revised and edited by Prof. Iraj Rasooli for important intellectual content.

\section{References}

1. Bucci DZ, Tavares LBB, Sell I. PHB packaging for the storage of food products. Polymer Testing. 2005;24(5):564-71.

2. Suresh Kumar M, Mudliar SN, Reddy KM, Chakrabarti T. Production of biodegradable plastics from activated sludge generated from a food processing industrial wastewater treatment plant. Bioresour Technol. 2004;95(3):327-30.

3. Choi J, Lee SY. Process analysis and economic evaluation for Poly(3-hydroxybutyrate) production by fermentation. Biopr Engin. 1997;17(6):335.

4. Verlinden RA, Hill DJ, Kenward MA, Williams CD, Radecka I. Bacterial synthesis of biodegradable polyhydroxyalkanoates. J Appl Microbiol. 2007;102(6):1437-49.

5. Mokhtari-Hosseini ZB, Vasheghani-Farahani E, HeidarzadehVazifekhoran A, Shojaosadati SA, Karimzadeh R, Khosravi Darani K. Statistical media optimization for growth and PHB production from methanol by a methylotrophic bacterium. Bioresour Technol. 2009;100(8):2436-43.

6. Lee SY. Plastic bacteria? Progress and prospects for polyhydroxyalkanoate production in bacteria. Trend Biotech.1996;14(11):431-8.

7. Tamber H, Johansen P, Merkle HP, Gander B. Formulation aspects of biodegradable polymeric microspheres for antigen delivery. Adv Drug Deliv Rev. 2005;57(3):357-76.
8. Holmes PA. Applications of PHB - a microbially produced biodegradable thermoplastic. Phys Technol.1985;16(1):32-6.

9. Beaulieu M, Beaulieu Y, Melinard J, Pandian S, Goulet J. Influence of Ammonium Salts and Cane Molasses on Growth of Alcaligenes eutrophus and Production of Polyhydroxybutyrate. Appl Environ Microbiol.1995;61(1):165-9.

10. Gouda MK, Swellam AE, Omar SH. Production of PHB by a Bacillus megaterium strain using sugarcane molasses and corn steep liquor as sole carbon and nitrogen sources. Microbiol Res. 2001;156(3):201-7.

11. Yu L, Lei T, Ren X, Pei X, Feng Y. Response surface optimization of l-(+)-lactic acid production using corn steep liquor as an alternative nitrogen source by Lactobacillus rhamnosus CGMCC 1466. Biochem Engin J. 2008;39(3):496-502.

12. Kim BS. Production of poly(3-hydroxybutyrate) from inexpensive substrates. Enzym Microbial Tec. 2000;27(10):774-7.

13. Burdon KL. Fatty Material in Bacteria and Fungi Revealed by Staining Dried, Fixed Slide Preparations. J Bacteriol.1946;52(6):665-78.

14. Slepecky RA, Law JH. SYNTHESIS AND DEGRADATION OF POLY-beta-HYDROXYBUTYRIC ACID IN CONNECTION WITH SPORULATION OF BACILLUS MEGATERIUM. J Bacteriol. 1961;82(1):37-42.

15. Law KH, Cheng YC, Leung YC, Lo WH, Chua H, Yu HF. Construction of recombinant Bacillus subtilis strains for polyhydroxyalkanoates synthesis. Biochem Engin J. 2003;16(2):203-8.

16. Lageveen RG, Huisman GW, Preusting H, Ketelaar P, Eggink G Witholt B. Formation of Polyesters by Pseudomonas oleovorans: Effect of Substrates on Formation and Composition of Poly-(R)3-Hydroxyalkanoates and Poly-(R)-3-Hydroxyalkenoates. Appl Environ Microbiol.1988;54(12):2924-32.

17. Holt JG, Krieg NR, Sneath PHA, Staley JT, Williams ST. Endosporeforming gram-positive rods and cocci.Bergey's Manual of Determinative Bacteriology. Baltimore USA: William and Wilkins; 1994

18. Reid NM, Bowers TH, Lloyd-Jones G. Bacterial community composition of a wastewater treatment system reliant on N2 fixation. Appl Microbiol Biotechnol. 2008;79(2):285-92.

19. Pouton CW, Akhtar S. Biosynthetic polyhydroxyalkanoates and their potential in drug delivery. Advanced Drug Delivery Rev. 1996;18(2):133-62.

20. Arun A, Arthi R, Shanmugabalaji V, Eyini M. Microbial production of poly-beta-hydroxybutyrate by marine microbes isolated from various marine environments. Bioresour Technol. 2009;100(7):2320-3.

21. Verma S, Bhargava R, Pruthi V. Oily sludge degradation by bacteria from Ankleshwar, India. I Biodeterioration \& Biodegra. 2006;57(4):207-13.

22. Ruan YJ, Zhu L, Xu XY. Study on the flocs poly-beta-hydroxybutyrate production and process optimization in the bio-flocs technology system. Bioresour Technol. 2011;102(16):7599-602.

23. Grousseau E, Blanchet E, Deleris S, Albuquerque MG, Paul E, Uribelarrea JL. Impact of sustaining a controlled residual growth on polyhydroxybutyrate yield and production kinetics in Cupriavidus necator. Bioresour Technol. 2013;148:30-8.

24. Deepak V, Kalishwaralal K, Ramkumarpandian S, Babu SV, Senthilkumar SR, Sangiliyandi G. Optimization of media composition for Nattokinase production by Bacillus subtilis using response surface methodology. Bioresour Technol. 2008;99(17):8170-4.

25. Zhang Y, Sun W, Wang H, Geng A. Polyhydroxybutyrate production from oil palm empty fruit bunch using Bacillus megaterium R11. Bioresour Technol. 2013;147:307-14.

26. Lee YH, Park JS, Huh TL. Biotech Letters. 1997;19(8):771-4

27. Quillaguaman J, Doan-Van T, Guzman H, Guzman D, Martin J, Everest A, et al. Poly(3-hydroxybutyrate) production by Halomonas boliviensis in fed-batch culture. Appl Microbiol Biotechnol. 2008;78(2):227-32.

28. Grothe E, Moo-Young M, Chisti Y. Fermentation optimization for the production of poly( $\beta$-hydroxybutyric acid) microbial thermoplastic. Enzyme and Microbial Tec. 1999;25(1-2):132-41. 